\title{
THE RELATIVE AGE EFFECT IN TURKISH PROFESSIONAL SOCCER
}

\author{
Yunus Arslan; Yusuf Köklü; Utku Alemdaroğlu; Hüseyin Gökçe
}

Faculty of Sports Sciences. Pamukkale University, Turkey.

\begin{abstract}
This study examined the Relative Age Effect (RAE) in Turkish professional soccer. The data on 3435 players $\left(M_{\text {Age }}=25.25, S D_{\text {Age }}=1.16\right)$ across 127 professional teams from the four Turkish professional leagues were categorized into relative age quartiles $(Q 1=J a n-M a r ; Q 2=A p r-J u n e ; Q 3=$ Jul-Sep; $Q 4=O c t-D e c$ ). Birth data and registration dates were collected through the Turkish Football Federation's official website. This data revealed a greater representation of players (approximately $62 \%$ ) born between January and June, with statistically significant values for all professional leagues $\left(X^{2}(3)=303.01 ; p<0.01\right)$. Similarly, domestic players $\left(X^{2}(3)=316.77 ; p<0.01\right)$ and foreign players $\left(X^{2}{ }_{(3)}=14.59 ; p<0.01\right)$ born in the Q1 and Q2 zones were more likely to be members of Turkish professional leagues than those born in other zones. The findings of the present study also showed a strong RAE for all playing positions $\left(40.37 \leq X^{2}(3) \leq 143.5 ; p<0.01\right)$. Based on the present data, players born in Q1 and Q2 zones, independently of the league level, position and nationality, seem to have advantages compared to those born in the rest of the year.
\end{abstract}

Keywords: relative age effect, playing positions, professional soccer

\section{EL EFECTO DE LA EDAD RELATIVA EN FÚTBOL PROFESIONAL TURCO}

\begin{abstract}
RESUMEN
Este estudio examinó el efecto de la edad relativa (RAE) en el fútbol profesional turco. Los datos sobre 3435 jugadores $\left(\mathrm{M}_{\text {Age }}=25.25, \mathrm{SD}_{\text {Age }}=1.16\right)$ en 127 equipos profesionales de las cuatro ligas profesionales turcas se clasificaron en cuartiles de edad relativos $(\mathrm{Q} 1$ = enero-marzo; $Q 2$ = abriljunio; Q3 = julio-septiembre; Q4 = Oct-Dic). La fecha de nacimiento y las fechas de registro se recopilaron a través del sitio web oficial de la Federación Turca de Fútbol. Estos datos revelaron una mayor representación de jugadores (aproximadamente 62\%) nacidos entre enero y junio, con valores estadísticamente significativos para todas las ligas profesionales $\left(\mathrm{X}^{2}{ }_{(3)}=303.01 ; \mathrm{p}<0.01\right)$. Del mismo modo, los jugadores nacionales $\left(\mathrm{X}^{2}{ }_{(3)}=316.77 ; \mathrm{p}<0.01\right)$ y los jugadores extranjeros $\left(\mathrm{X}^{2}\right.$ $(3)=14.59 ; \mathrm{p}<0.01)$ nacidos en las zonas Q1 y Q2 tenían más probabilidades de ser miembros de ligas profesionales turcas que aquellos nacido en otras zonas. Los resultados del presente estudio también mostraron un RAE fuerte para todas las posiciones de juego $\left(40.37 \leq X^{2}\right.$ (3) $\left.\leq 143.5 ; p<0.01\right)$. Según los datos actuales, los jugadores nacidos en las zonas Q1 y Q2, independientemente del nivel de liga, posición y nacionalidad, parecen tener ventajas en comparación con los nacidos en el resto del año.
\end{abstract}

Palabras clave: efecto de edad relativa, posiciones de juego, fútbol profesional

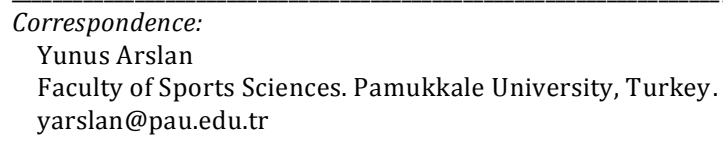

Submitted: 06/04/2020

Accepted: 19/06/2020 


\section{INTRODUCTION}

In many sports, children are grouped chronologically for the purpose of providing developmentally appropriate instruction, fair competition, and equal opportunity. The selection period is generally established between 1 January and 31 December. As a consequence, children born towards the beginning of this period may be more advanced in cognitive, emotional and physical terms those born later, but will still compete in the same category every season (Jimenez \& Pain, 2008; Malina, 1994; Musch \& Grondin, 2001).

The term 'relative age' refers to a person's age relative to that of his/her peers within the same annual group. The variations in age within an annual age group have been referred to as 'relative age differences', and their consequences as the 'relative age effect' (RAE) (Gil et al., 2014; Wattie, Cobley \& Baker, 2008).

The underlying causes of the RAE have not been distinguished empirically, nonetheless consensus holds that players born in the early months of the section year are likely at a physical advantage due to normative growth and/or biological maturation, and in the early stages of participation possess greater playing experience (Lovell et al., 2015). The RAE manifests itself when a significant degree of competition is present, and several competitive sports are breeding grounds for RAE because weight, height and strength are important (e.g., soccer, ice hockey, American football, baseball, basketball, cricket and tennis). Moreover, the evidence for the RAE is not strong in sports such as gymnastics or dance, because movement competency is more important and having a large body size or mass may present a disadvantage to the athlete (Delorme, Boiche, \& Raspaud, 2010; Helsen et al., 2012; Musch \& Grondin, 2001).

The RAE phenomenon is found worldwide in soccer. Most studies of the RAE have tried to test the hypothesis that the month of birth and maturity status could be determining factors in soccer players' success. Some prominent researchers (Carling et al., 2009; Jullien et al., 2008; Mujika et al., 2007; Sherar et al., 2007) stress that the RAE is more relevant in high-level teams. Thus, studies across a range of countries have analyzed this phenomenon by focusing on professional leagues (Bäumler, 2000; Dudink, 1994; Helsen et al., 1998; 2000; 2005; Musch \& Hay, 1999; Verhulst, 1992; Yague et al., 2018). Most of the results of these studies reveal a significant over-representation of players born in the early part of the selection year.

The conclusion commonly drawn is that the percentage of players born early in the selection year is particularly high in professional soccer leagues because talent identification and selection processes within elite youth academies tend to aggravate the RAE (Carling et al., 2009; Jullien et al., 2008; Mujika et al., 2007). This point then raises the question of what criteria coaches 
use to discover talented youth soccer players. Some predictions have been made that players may be perceived as being more "talented" and selected purely because of maturity related advantages in body size, strength, speed and endurance (Carling et al., 2009).

Coaches may be under the impression that older, more physically developed players have superior performance in all fitness variables. Thus, when the smaller players are not selected, they do not have the advantage of better coaching, teammates, and competition and as a result fall behind in skill performance and are more likely to drop-out of the sport (Kirkendall, 2014). In other words, the interplay of a variety of factors including physical, cognitive, emotional, and motivational causes could explain the RAE, and only coaches who are fully aware of the struggles of children born later in the year may be prepared to offset the disappointment and setbacks these children encounter (Musch \& Grondin, 2001).

Until now, no strategies have been implemented to combat the negative consequences of a low relative age (Musch \& Grondin, 2001) although it has been consistently described in many professional soccer leagues in several countries as a probable cause of the potential waste of talented players. For Turkey, only a limited number of studies (Koklu, Arslan, \& Alemdaroglu, 2017; Mulazımoglu et al, 2013; Yague et al., 2018) have explicitly attempted to track the RAE, and evidence does not cover all levels of professional soccer. In the present study, therefore, the hypothesis was tested that the RAE will be found among Turkish and Foreign professional soccer players.

\section{Method}

\section{Participants}

In Turkey, there are four official men's professional soccer leagues; the Super League (SL), League 1 (L1), League 2 (L2) and League 3 (L3). From these leagues, all players were included in this study and the data on 3435 players $\left(M_{\text {Age }}=25.25, \mathrm{SD}_{\text {Age }}=1.16\right)$ in 127 professional teams were analyzed. The sample consisted of 462 players from the 18 teams in the SL, 457 from the 18 teams in L1, 971 from the 36 teams in L2, and 1545 players from the 53 teams in L3. Amongst these, there were 189 foreign players in the SL and 105 in L1, with no foreign players in L2 or L3. In terms of positions, 414 players were goalkeepers, while 1097 were classed as defenders, 1396 as midfielders, and 528 as forwards. The data was collected for the 2015-2016 competitive season.

\section{Procedure}

Birth data and registration dates were collected by accessing the Turkish Football Federation's official website (www.tff.org) which holds information for all licensed players. To determine the RAE, player birthdates within a specific 
league were categorized into birth quartiles (Q). The first quartile (Q1) comprised players with birthdays between 1 January and 31 March, the second quartile (Q2) those born from 1 April to 30 June, the third quartile (Q3) those born from 1 July to 30 September and the final group (Q4) was composed of players born from 1 October to 31 December.

\section{Statistics}

The results are presented in terms of frequency and percentage to summarize the data. To test the extent of the RAE in each professional league (i.e., SL, L1, L2, L3), a chi-square test was used to assess the observed and expected birth distribution across the sample of players. Using the national population for expected values provide a more accurate measure of the RAE (Delorme \& Champely, 2015). For this study, we obtained expected distribution (i.e., the percentage of births in each quartile in Turkey) from the Turkish Statistical Institute's official website (www.turkstat.gov.tr). Chi-square values were followed up by calculating Odds Ratios (OR) and 95\% Confidence Intervals $(95 \% C I)$ for the quartile distributions in order to examine subgroup differences. The ORs compared the birth-date distribution of a particular quartile (Q1, Q2 or Q3) with the reference group, which consisted of the youngest players (Q4). A higher OR indicates an increased incidence of players who were born in that particular quartile compared to the reference quartile Q4.

\section{RESUlts}

The proportions of players born between July and December were lower than the proportions of players born during the first six months, with the majority of players (approximately 62\%) born between January and June (see Table 1). The chi-square analyses revealed that the highest number of players were born in the Q1 zone, followed by the Q2, Q3 and, finally Q4 for the total sample $\left(X^{2}(3)=303.01 ; p=0.00\right)$ and in each league level $\left(15.48 \leq X^{2}(3) \leq 172.31\right.$; $p<0.01 ; 0.68 \leq O R \leq 1.23$ ).

The RAE was significant for the total sample of domestic players $\left(X^{2}{ }_{(3)}=\right.$ 316.77; $p<0.01$ ), with significant differences found for each league level $\left(18.61 \leq X^{2}{ }_{(3)} \leq 172.31 ; p<0.01 ; 0.66 \leq O R \leq 1.54\right)$. Similarly the effect was significant for the total sample of foreign players $\left(X^{2}{ }_{(3)}=14.59 ; p<0.01\right)$, and for the SL $\left(X^{2}{ }_{(3)}=10.21 ; p=0.01 ; 1.18 \leq O R \leq 1.31\right)$. With $\mathrm{Q} 4$ as the reference zone, domestic and foreign players in the Turkish professional soccer leagues were more likely to be born in the Q1 and Q2 zones, with the exception of foreign players in L1 (see Table 1). 
TABLE 1

Quarterly distribution of birth dates for Turkish and Foreign soccer players in Turkish professional soccer teams for the year 2015-16.

\begin{tabular}{|c|c|c|c|c|c|c|c|c|c|c|c|}
\hline \multirow[b]{2}{*}{ Players } & \multirow[b]{2}{*}{ LL } & \multirow[b]{2}{*}{$\mathbf{n}$} & \multicolumn{4}{|c|}{ Quarter of Birth } & \multicolumn{4}{|c|}{ OR Comparisons [95\%CI] } & \multirow[b]{2}{*}{$\begin{array}{c}\text { Pairwise } \\
\text { Comparisons }\end{array}$} \\
\hline & & & $\begin{array}{c}Q_{1} \\
(\%) \\
(\text { Exp.) }\end{array}$ & $\begin{array}{c}Q_{2} \\
(\%) \\
(\text { Exp.) }\end{array}$ & $\begin{array}{c}Q_{3} \\
(\%) \\
(\text { Exp.) }\end{array}$ & $\begin{array}{c}Q_{4} \\
(\%) \\
(\text { Exp.) }\end{array}$ & $X^{2}$ & $Q 1$ vs. $Q 4$ & $Q 2$ vs. $Q 4$ & $Q 3$ vs. Q4 & \\
\hline \multirow{5}{*}{ Turkish } & SL & 273 & $\begin{array}{c}111 \\
(40.60) \\
(102)\end{array}$ & $\begin{array}{c}50 \\
(18.31) \\
(66)\end{array}$ & $\begin{array}{c}78 \\
(28.57) \\
(64)\end{array}$ & $\begin{array}{c}34 \\
(12.45) \\
(41)\end{array}$ & $50.23^{a}$ & $\begin{array}{c}1.36 \\
(0.91-2.03)\end{array}$ & $\begin{array}{c}0.92 \\
(0.58-1.44)\end{array}$ & $\begin{array}{c}1.54 \\
(1.01-2.35)^{b}\end{array}$ & $\begin{array}{l}\text { Q1-Q2 } \\
\text { Q1-Q4 }\end{array}$ \\
\hline & L1 & 352 & $\begin{array}{c}118 \\
(33.52) \\
(131)\end{array}$ & $\begin{array}{c}85 \\
(24.14) \\
(84)\end{array}$ & $\begin{array}{c}88 \\
(25.00) \\
(82)\end{array}$ & $\begin{array}{c}61 \\
(17.32) \\
(55)\end{array}$ & $18.61^{a}$ & $\begin{array}{c}0.76 \\
(0.54-1.06)\end{array}$ & $\begin{array}{c}0.86 \\
(0.60-1.22)\end{array}$ & $\begin{array}{c}0.92 \\
(0.65-1.31)\end{array}$ & Q1-Q4 \\
\hline & $\mathbf{L 2}$ & 971 & $\begin{array}{c}362 \\
(37.28) \\
(362)\end{array}$ & $\begin{array}{c}228 \\
(23.48) \\
(233)\end{array}$ & $\begin{array}{c}222 \\
(22.86) \\
(228)\end{array}$ & $\begin{array}{c}159 \\
(16.37) \\
(148)\end{array}$ & $90.14^{a}$ & $\begin{array}{c}0.89 \\
(0.71-1.12)\end{array}$ & $\begin{array}{c}0.86 \\
(0.67-1.10)\end{array}$ & $\begin{array}{c}0.66 \\
(0.67-1.10)\end{array}$ & Q1-Q4 \\
\hline & L3 & 1545 & $\begin{array}{c}582 \\
(37.66) \\
(577)\end{array}$ & $\begin{array}{c}393 \\
(25.43) \\
(372)\end{array}$ & $\begin{array}{c}347 \\
(22.45) \\
(362)\end{array}$ & $\begin{array}{c}223 \\
(14.43) \\
(234)\end{array}$ & $172.31^{a}$ & $\begin{array}{c}1.12 \\
(0.90-1.38)\end{array}$ & $\begin{array}{c}1.23 \\
(0.98-1.55)\end{array}$ & $\begin{array}{c}1.01 \\
(0.80-1.28)\end{array}$ & $\begin{array}{l}\text { Q1-Q4 } \\
\text { Q2-Q4 } \\
\text { Q3-Q4 }\end{array}$ \\
\hline & Total & 3141 & 1173 & 756 & 735 & 477 & $316.77 a$ & - & - & - & $\begin{array}{l}\text { Q1-Q4 } \\
\text { Q2-Q4 } \\
\text { Q3-Q4 } \\
\end{array}$ \\
\hline \multirow{5}{*}{ Foreign } & SL & 189 & $\begin{array}{c}52 \\
(27.51) \\
(51)\end{array}$ & $\begin{array}{c}63 \\
(33.33) \\
(63)\end{array}$ & $\begin{array}{c}36 \\
(19.04) \\
(35)\end{array}$ & $\begin{array}{c}38 \\
(20.10) \\
(40)\end{array}$ & $10.21^{b}$ & $\begin{array}{c}1.31 \\
(0.65-2.62)\end{array}$ & $\begin{array}{c}1.18 \\
(0.61-2.27)\end{array}$ & $\begin{array}{c}1.24 \\
(0.58-2.64)\end{array}$ & $\begin{array}{l}\text { Q1-Q4 } \\
\text { Q2-Q4 }\end{array}$ \\
\hline & L1 & 105 & $\begin{array}{c}26 \\
(24.76) \\
(28)\end{array}$ & $\begin{array}{c}35 \\
(33.33) \\
(35)\end{array}$ & $\begin{array}{c}19 \\
(18.09) \\
(20)\end{array}$ & $\begin{array}{c}25 \\
(23.80) \\
(22)\end{array}$ & 4.98 & $\begin{array}{c}0.76 \\
(0.38-1.51)\end{array}$ & $\begin{array}{c}0.84 \\
(0.43-1.62)\end{array}$ & $\begin{array}{c}0.80 \\
(0.37-1.69)\end{array}$ & - \\
\hline & $\mathbf{L} 2$ & - & - & - & - & - & - & - & - & - & - \\
\hline & L3 & - & - & - & - & - & - & - & - & - & - \\
\hline & Total & 294 & 78 & 98 & 55 & 63 & $14.59^{a}$ & - & - & - & $\begin{array}{l}\text { Q1-Q3 } \\
\text { Q2-Q3 }\end{array}$ \\
\hline
\end{tabular}


TABLE 1 (Cont.)

\begin{tabular}{|c|c|c|c|c|c|c|c|c|c|c|c|}
\hline \multirow{5}{*}{ All } & SL & 462 & $\begin{array}{c}163 \\
(35.28) \\
(168)\end{array}$ & $\begin{array}{c}113 \\
(24.45) \\
(115)\end{array}$ & $\begin{array}{c}114 \\
(24.67) \\
(106)\end{array}$ & $\begin{array}{c}72 \\
(15.58) \\
(73)\end{array}$ & $35.99^{a}$ & $\begin{array}{c}0.97 \\
(0.72-1.31)\end{array}$ & $\begin{array}{c}0.99 \\
(0.72-1.36)\end{array}$ & $\begin{array}{c}1.09 \\
(0.79-1.50)\end{array}$ & Q1-Q4 \\
\hline & L1 & 457 & $\begin{array}{c}144 \\
(31.50) \\
(166)\end{array}$ & $\begin{array}{c}120 \\
(26.25) \\
(113)\end{array}$ & $\begin{array}{c}107 \\
(23.41) \\
(105)\end{array}$ & $\begin{array}{c}86 \\
(18.81) \\
(73)\end{array}$ & $15.48^{a}$ & $\begin{array}{c}0.68 \\
(0.51-0.91)^{b}\end{array}$ & $\begin{array}{c}0.86 \\
(0.63-1.16)\end{array}$ & $\begin{array}{c}0.82 \\
(0.60-1.12)\end{array}$ & Q1-Q4 \\
\hline & L2 & 971 & $\begin{array}{l}362 \\
(37.28) \\
(354)\end{array}$ & $\begin{array}{c}228 \\
(23.48) \\
(241)\end{array}$ & $\begin{array}{c}222 \\
(22.86) \\
(223)\end{array}$ & $\begin{array}{c}159 \\
(16.37) \\
(153)\end{array}$ & $90.14^{a}$ & $\begin{array}{c}0.97 \\
(0.78-1.21)\end{array}$ & $\begin{array}{c}0.87 \\
(0.68-1.10)\end{array}$ & $\begin{array}{c}0.93 \\
(0.73-1.19)\end{array}$ & $\begin{array}{l}\text { Q1-Q4 } \\
\text { Q2-Q4 } \\
\text { Q3-Q4 }\end{array}$ \\
\hline & L3 & 1545 & $\begin{array}{c}582 \\
(37.66) \\
(563)\end{array}$ & $\begin{array}{c}393 \\
(25.43) \\
(385)\end{array}$ & $\begin{array}{c}347 \\
(22.45) \\
(355)\end{array}$ & $\begin{array}{c}223 \\
(14.43) \\
(242)\end{array}$ & $172.31^{a}$ & $\begin{array}{c}1.23 \\
(1.00-1.51)^{b}\end{array}$ & $\begin{array}{c}1.21 \\
(0.97-1.50)\end{array}$ & $\begin{array}{c}1.11 \\
(0.89-1.38)\end{array}$ & $\begin{array}{l}\text { Q1-Q4 } \\
\text { Q2-Q4 } \\
\text { Q3-Q4 }\end{array}$ \\
\hline & Total & 3435 & 1251 & 854 & 790 & 540 & $303.01^{a}$ & - & - & - & $\begin{array}{l}\text { Q1-Q4 } \\
\text { Q2-Q4 }\end{array}$ \\
\hline
\end{tabular}

Note: $L L$ : League Level; $S L=$ Super League; $L 1=$ League $1 ; L 2=$. League 2; $L 3=$ League $3 ; n=$ sample size; $Q=$ quartile; $O R=$ odds ratio; $C I=$ confidence interval for odds ratio; numbers in parentheses below the first value in a line represent the observed percentage of each $Q$, and the number in parentheses below that represents the expected value for each $Q ; a p<0.01 ; b p<0.05$. 
The present study also explored the RAE for different playing positions (see Table 2). Players born in the earlier months were overrepresented in all positions, with significant differences found for each position $\left(40.37 \leq X^{2}{ }_{(3)} \leq\right.$ $143.5 ; p<0.01)$.

Except for the fact that the birth-date distributions of players were not significantly different in L1 for any playing position nor in the SL for goalkeeper and forward position ( $p>0.05$ ), distributions were significantly biased towards a higher number of births during the first six months (see Table 2). In other words, the likelihood of being a member of L2 and L3 as goalkeeper; SL, L2 and L3 as defender; SL, L2 and L3 as midfielder, and finally, L2 and L3 as forward when born in Q1 or Q2 zones was higher than Q3 and Q4. 
TABLE 2

Quarterly distribution of birth dates for positions of soccer players in Turkish professional soccer teams.

\begin{tabular}{|c|c|c|c|c|c|c|c|c|c|c|c|}
\hline \multirow[b]{2}{*}{$\begin{array}{c}\text { Player } \\
\text { Position }\end{array}$} & \multirow[b]{2}{*}{$\mathbf{L L}$} & \multirow[b]{2}{*}{$\mathbf{n}$} & \multicolumn{4}{|c|}{ Quarter of Birth } & \multicolumn{4}{|c|}{ OR Comparisons [95\% CI] } & \multirow[b]{2}{*}{$\begin{array}{c}\text { Pairwise } \\
\text { Comparison }\end{array}$} \\
\hline & & & $\begin{array}{c}Q_{1} \\
(\%) \\
(\text { Exp. })\end{array}$ & $\begin{array}{c}Q_{2} \\
(\%) \\
(\text { Exp. })\end{array}$ & $\begin{array}{c}Q_{3} \\
(\%) \\
(\text { Exp. })\end{array}$ & $\begin{array}{c}Q_{4} \\
(\%) \\
(\text { Exp. })\end{array}$ & $X^{2}$ & $Q 1$ vs. $Q 4$ & $Q 2$ vs. $Q 4$ & Q3 vs. Q4 & \\
\hline \multirow{5}{*}{ GK } & SL & 62 & $\begin{array}{c}21 \\
(33.87) \\
(23)\end{array}$ & $\begin{array}{c}16 \\
(25.80) \\
(16)\end{array}$ & $\begin{array}{c}12 \\
(19.35) \\
(11)\end{array}$ & $\begin{array}{c}13 \\
(20.96) \\
(12)\end{array}$ & 3.16 & $\begin{array}{c}0.77 \\
(0.36-1.63)\end{array}$ & $\begin{array}{c}0.86 \\
(0.38-1.92)\end{array}$ & $\begin{array}{c}0.93 \\
(0.39-2.21)\end{array}$ & - \\
\hline & L1 & 54 & $\begin{array}{c}20 \\
(37.03) \\
(20)\end{array}$ & $\begin{array}{c}16 \\
(29.62) \\
(14)\end{array}$ & $\begin{array}{c}11 \\
(20.37) \\
(10)\end{array}$ & $\begin{array}{c}7 \\
(12.96) \\
(10)\end{array}$ & 7.18 & $\begin{array}{c}1.48 \\
(0.59-3.67)\end{array}$ & $\begin{array}{c}1.75 \\
(0.68-4.50)\end{array}$ & $\begin{array}{c}1.71 \\
(0.62-4.70)\end{array}$ & - \\
\hline & $\mathbf{L 2}$ & 117 & $\begin{array}{c}43 \\
(36.75) \\
(44)\end{array}$ & $\begin{array}{c}32 \\
(27.35) \\
(30)\end{array}$ & $\begin{array}{c}21 \\
(17.94) \\
(21)\end{array}$ & $\begin{array}{c}21 \\
(17.94) \\
(22)\end{array}$ & $11.37^{b}$ & $\begin{array}{c}1.02 \\
(0.55-1.88)\end{array}$ & $\begin{array}{c}1.13 \\
(0.59-2.18)\end{array}$ & $\begin{array}{c}1.03 \\
(0.50-2.11)\end{array}$ & $\begin{array}{l}\text { Q1-Q3/Q4 } \\
\text { Q2-Q3/Q4 }\end{array}$ \\
\hline & $\mathbf{L 3}$ & 181 & $\begin{array}{c}71 \\
(39.22) \\
(68)\end{array}$ & $\begin{array}{c}43 \\
(23.75) \\
(46)\end{array}$ & $\begin{array}{c}31 \\
(17.12) \\
(33)\end{array}$ & $\begin{array}{c}36 \\
(19.88) \\
(34)\end{array}$ & $21.14^{a}$ & $\begin{array}{c}0.96 \\
(0.55-1.66)\end{array}$ & $\begin{array}{c}0.52 \\
(0.29-0.92)^{b}\end{array}$ & $\begin{array}{c}0.80 \\
(0.42-1.52)\end{array}$ & $\begin{array}{l}\text { Q1-Q3/Q4 } \\
\text { Q2-Q3/Q4 }\end{array}$ \\
\hline & Total & 414 & 155 & 107 & 75 & 77 & $40.37^{a}$ & - & - & - & $\begin{array}{l}\text { Q1-Q3/Q4 } \\
\text { Q2-Q3/Q4 }\end{array}$ \\
\hline \multirow{5}{*}{ DF } & SL & 141 & $\begin{array}{c}38 \\
(26.95) \\
(50)\end{array}$ & $\begin{array}{c}35 \\
(24.82) \\
(34)\end{array}$ & $\begin{array}{c}46 \\
(32.62) \\
(35)\end{array}$ & $\begin{array}{c}22 \\
(15.60) \\
(22)\end{array}$ & $8.47^{b}$ & $\begin{array}{c}0.74 \\
(0.42-1.29)\end{array}$ & $\begin{array}{c}1.05 \\
(0.59-1.86)\end{array}$ & $\begin{array}{c}1.48 \\
(0.85-2.56)\end{array}$ & Q3-Q4 \\
\hline & L1 & 141 & $\begin{array}{c}46 \\
(32.62) \\
(50)\end{array}$ & $\begin{array}{c}33 \\
(23.40) \\
(34)\end{array}$ & $\begin{array}{c}38 \\
(26.95) \\
(34)\end{array}$ & $\begin{array}{c}24 \\
(17.02) \\
(23)\end{array}$ & 7.22 & $\begin{array}{c}0.83 \\
(0.48-1.41)\end{array}$ & $\begin{array}{c}0.89 \\
(0.50-1.56)\end{array}$ & $\begin{array}{c}1.06 \\
(0.61-1.85)\end{array}$ & - \\
\hline & $\mathbf{L 2}$ & 297 & $\begin{array}{c}111 \\
(37.37) \\
(107)\end{array}$ & $\begin{array}{c}62 \\
(20.87) \\
(72)\end{array}$ & $\begin{array}{c}69 \\
(23.23) \\
(71)\end{array}$ & $\begin{array}{c}55 \\
(18.51) \\
(47)\end{array}$ & $25.57^{a}$ & $\begin{array}{c}0.85 \\
(0.58-1.26)\end{array}$ & $\begin{array}{c}0.66 \\
(0.43-1.01)\end{array}$ & $\begin{array}{c}0.78 \\
(0.51-1.18)\end{array}$ & Q1-Q4 \\
\hline & $\mathbf{L 3}$ & 518 & $\begin{array}{c}199 \\
(38.41) \\
(187)\end{array}$ & $\begin{array}{c}136 \\
(26.25) \\
(126)\end{array}$ & $\begin{array}{c}109 \\
(21.04) \\
(123)\end{array}$ & $\begin{array}{c}74 \\
(14.28) \\
(82)\end{array}$ & $64.55^{a}$ & $\begin{array}{c}1.39 \\
(0.97-1.99)\end{array}$ & $\begin{array}{c}1.42 \\
(0.97-2.09)\end{array}$ & $\begin{array}{c}0.97 \\
(0.65-1.43)\end{array}$ & $\begin{array}{l}\text { Q1-Q4 } \\
\text { Q2-Q4 }\end{array}$ \\
\hline & Total & 1097 & 394 & 266 & 262 & 175 & $89.00^{a}$ & - & - & - & Q1-Q4 \\
\hline
\end{tabular}


TABLE 2 (Cont.)

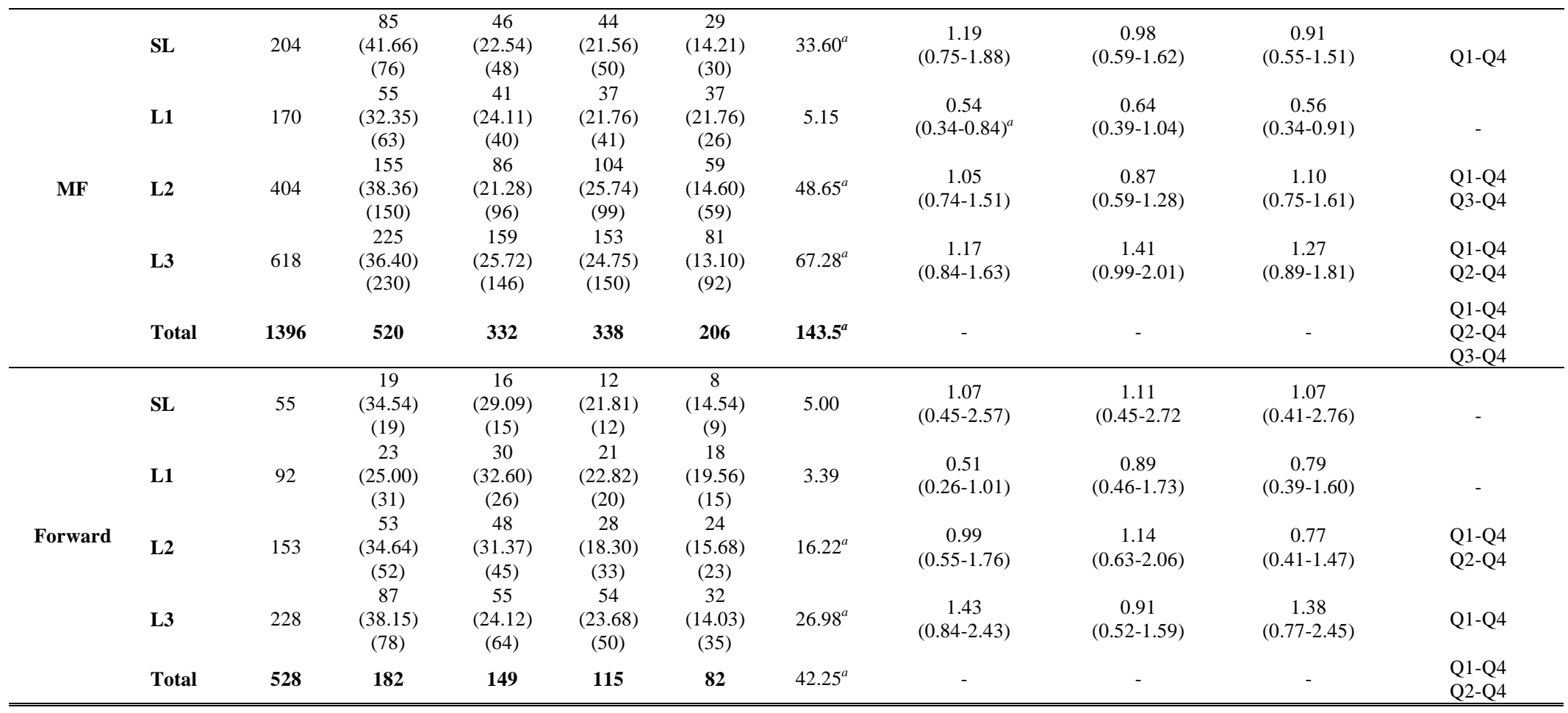

Note: GK: Goalkeeper; DF: Defender; MF: Midfielder; LL: League Level; SL=Super League; L1= League 1; L2=. League 2; L3 = League 3; $n=$ sample size; Q= quartile; $O R=$ odds ratio; $C I=$ confidence interval for odds ratio; numbers in parentheses below the first value in a line represent the observed percentage of each $Q$, and the number in parentheses below that represents the expected value for each $Q ;{ }^{a} p<0.01 ;{ }^{b} p<0.05$. 


\section{DISCUSSION}

The present study has analysed the extent to which the RAE exists among players in Turkish professional soccer leagues. This study therefore contributes further evidence to the extensive and growing literature regarding the existence of the RAE in soccer.

The results of this study revealed a biased distribution of professional soccer players in favor of players born during the first months of the year. This conclusion has also been reached by previous researches (Dudink, 1994; Helsen et al., 2005; Ishigami, 2016; Jimenez \& Pain, 2008; Musch \& Hay, 1999; Verhulst, 1992; Yague et al., 2018; Wiium, 2010). Yague et al. (2018) studied the RAE in the ten national professional men's soccer leagues of the UEFA Confederation, and determined that the probability of belonging to Q1 is statistically significant for Turkey's SL. In addition, Koklu et al. (2017) found that among young soccer players in the elite youth academies of professional clubs in Turkey, players born in the later months of the year are less likely to be selected as professional. As a result, the present study results were not surprising for domestic players; and moreover, the trend was also found for foreign soccer players in Turkey.

The overrepresentation of professional soccer players born early in the selection year would seem to support the suggestion that talent identification and selection in soccer during early adolescence appear to be influenced significantly by a child's physical attributes rather than skill (Carling et al, 2009; Helsen et al., 2000). Consistent with the opinion of Mush and Grondin (2001), players previously identified as being more mature or physically larger can be given more practice or opportunities for learning, thereby facilitating their development and eventual selection. This factor may provide relatively older players with a significant advantage in relation to the development of technical and game intelligence skills (Helsen et al., 2005; Ward \& Williams, 2003; Williams, 2000). Moreover, Hancock et al. (2013) designed a social agent model to explain RAE and discussed Matthew, Galatea and Pygmalion effects. In their model, they stated that the coach selections related to RAE would be influenced by parental enrolment decision (Matthew), self-expectations that athletes possess (Galatea) and coaches' and parents' higher expectations on relatively older athletes (Pygmalion). Examining the structures of this model may help to reduce RAE to create equal opportunities. In addition to this, Pena-Conzalez et al. (2018) stressed that coaches' efficacy expectations are also related to the RAE. In other words, the belief that relatively older players are taller, heavier or have better physical performance is the main factor driving the RAE.

A few suggestions have been made to reduce the RAE (Boucher \& Halliwell, 1991; Sedano, et al., 2015) for soccer players and these may result in less emphasis being placed on physical differences in lower-league development 
programs and in professional leagues: (a) coaches should not focus only on the physical maturity of players, but also on their talent; (b) a yearly rotation in cut-off date should be used, since all players would then experience the advantage of a higher relative age at some point, (c) physical tests should be repeated periodically in the talent identification process to account for variations in physical development because during growing process and (d) finally, more age categories with a smaller bandwidth (e.g. one year instead of two) could be created.

Since both cognitive and motor skills are important for children's sport development (French \& Thomas, 1987), coaching should not only concentrate on motor skills, but also teaching sport-specific procedural knowledge and cognitive skills such as knowledge of the rules of the game, optimal player positions, and there is also a need to focus on game strategies (Bunker \& Thorpe, 1983; Musch \& Grondin, 2001). It should also not be forgotten that players who mature early might face frustration because their success is based on transient advantages and their careers may not develop as they may expect (Ostojic et al., 2014).

In this study, we sought to determine the possible influence of playing position on RAE. The findings of the present study, as predicted, suggested that the effect also exists for the overall sample of professional soccer players for all playing positions. With the exception of some playing positions in some league levels (i.e., SL and L1), the vast majority of the birth-date distributions were significantly biased towards a higher number of births during the early part of the selection year (see Table 2). In other words, pairwise comparisons showed that all playing positions are more likely to hold more Q1 and Q2 zone players, with the exception of SL and L1 league levels. It may be stated that being a SL and L1 players in these playing positions (i.e., goalkeeper, defender, midfielder or forward) is not affected by relative age in Turkey. Similar findings were found in other studies of soccer players, both male (Sallaoui et al., 2014; Malina et al., 2004) and female (Sedano et al., 2015). However, Del Campo et al. (2010) reported that there was no significant difference related to the distribution of players in terms of playing position. The abovementioned studies were conducted with young players in youth academies, so it may be concluded that the current study provides the most extensive findings related to playing position amongst male professional soccer players.

In soccer, advanced maturation may improve performance (i.e., speed, strength, agility, ball-control, and co-ordination) across all positions, like many other sports (e.g. forwards in rugby union, goalkeepers in ice hockey who wear heavy equipment) (Sallaoui et al., 2014). This could explain why coaches tend to select relatively older players because of their physical maturity (Sedano, Vaeyens \& Redondo, 2015). Forwards and defenders who are more physically 
developed may have a small advantage in speed and power, whereas midfielders who are more developed may have advantage in terms of aerobic resistance (Malina et al., 2004). Additionally, according to Di Salvo and Pigozzi (1998), goalkeeper and defender are more physically demanding positions in soccer. The present results are thus consistent with the general observation of maturational theories that selection for all playing positions, whether goalkeepers, defenders, midfielders or forwards, could be influenced by distinct advantages associated with advanced biological maturation; the presence of the RAE might also in part be position dependent in soccer (Romann and Fuchslocher, 2011; Sedano et al., 2015; Weir et al., 2010).

\section{CONCLUSIONS}

Based on the present data, players born in Q1 and Q2 zones, independently of the league level, position and nationality, seem to have advantages compared to those born in the rest of the year. As noted in early studies (Barnsley \& Thompson, 1988; Boucher \& Halliwell, 1991), the main reasons for the RAE in professional soccer players could be the selection processes of youth players. In addition to all abovementioned options to reduce the RAE in discussion section, talent identification models should also make an effort to identify both physical and psychological mechanisms of Q3 and Q4 zone soccer players who met the criteria for entry into the elite youth academies and then professional league levels.

\section{ACKNOWLEDGEMENTS}

Part of this study was presented at the International Balkan Conference in Sport Sciences, 21-23 May 2017, Bursa, Turkey

\section{REFERENCES}

Bäumler, G. (2000). The relative age effect in soccer and its interaction with chronological age. Sportonomics, 6, (1), 25-30.

Barnsley, R. H., \& Thompson, A. H. (1988). Birth-date and success in minor hockey: the key to the NHL. Canadian Journal of Behavioral Science, 20, 167176.

Boucher, J., \& Halliwell, W. (1991). The novem system: A practical solution to age grouping. Canadian Association for Health, Physical Education \& Recreation, 57, 16-20.

Bunker, D., \& Thorpe, R. (1983). A model for the teaching of games in secondary schools. Bulletin of Physical Education, 19, 5-8.

Carling, C., le Gall, F., Reilly, T., Williams, A. M. (2009). Do anthropometric and fitness characteristics vary according to birth date distribution in elite youth 
academy soccer players? Scandinavian Journal of Medicine and Science in Sports, 19, 3-9.

Delorme, N., Champely, S. (2015). Relative age effect and chi-squared statistics. International Review for the Sociology of Sport, 50(5), 740-746.

Delorme, N., Boiche, J., \& Raspaud, M. (2010). Relative age effect in female sport: A diachronic examination of soccer players. Scandinavian Journal of Medicine and Science in Sports, 20, 509-515.

Di Salvo, V., Pigozzi F. (1998). Physical training of football players based on their positional rules in the team- Effects on performance-related factors. The Journal of Sports Medicine and Physical Fitness, 38(4), 294-297.

Dudink, A. (1994). Birth date and sporting success. Nature, 368, 592.

French, K., \& Thomas, J. (1987). The relation of knowledge development to children's basketball performance. Journal of Sport Psychology, 9, 15-32.

Gill, S. M., Badiola, A., Bidaurrazaga-Letona, I., Zabala-Lili, J., Gravina, L., SantosConcejero, J. (2014). Relationship between the relative age effect and anthropometry, maturity and performance in young soccer players. Journal of Sports Sciences, 32(5), 47986. http://doi.org/10.1080/02640414.2013.832355.

Hancock, D.J., adler, A.L., Cote, J. (2013). A proposed theoretical model to explain relative age effects in sport, European Journal of Sport Science, 13 (6), 630-637, DOI: 10.1080/17461391.2013.775352.

Helsen, W.F., Baker, J., Michiels, S., Schorer, J., Van Winckel, J., \& Williams, A.M. (2012). The relative age effect in European professional soccer: Did ten years of research make any difference? Journal of Sports Sciences, 30(15), 1665-1671. DOI: 10.1080/ 02640414.2012.721929.

Helsen, W., Winckel, J.V. and Willians, A.M. (2005). The relative age effect in youth soccer across Europe. Journal of Sport Sciences, 23(6), 629-636.

Helsen, W.F., Janet, L., Starkes, J.L. and Winckel, J.V. (1998). The influence of relative age on success and dropout in male soccer players. American Journal of Human Biology 12, 729-735.

Helsen, W.F., Starkes, J.L. and Winckel, J.V. (2000). Effect of a change in selection year on success in male soccer players. American Journal of Human Biology, 12, 729-735.

Ishigami, H. (2016) Relative age and birthplace effect in Japanese professional sports: a quantitative evaluation using a Bayesian hierarchical Poisson model, Journal of Sports Sciences, 34, (2), 143-154, DOI: 10.1080/02640414.2015.1039462

Jiménez, I.P. \& Pain, M.T.G. (2008). Relative age effect in Spanish association football: Its extent and implications for wasted potential, Journal of Sports Sciences, 26(10), 995-1003, DOI: 10.1080/02640410801910285. 
Jullien, H., Turpin, B., Carling, C. (2008). Influence of birth date on the career of French professional soccer players. Sci Sports, 23, 149-155.

Lovell, R., Towlson, C., Parkin, G., Portas, M., Vaeyens, R., Cobley, S. (2015). Soccer Player Characteristics in English Lower-League Development Programmes: The Relationships between Relative Age, Maturation, Anthropometry and Physical Fitness. PLOS ONE, 10, 9, 11-14, DOI:10.1371/journal.pone.0137238.

Kirkendall, D.T. (2014). The relative age effect has no influence on match outcome in youth soccer. Journal of Sport and Health Science, 3, 273-278. DOI: 10.1016/j.jshs.2014.07.001.

Koklu, Y., Arslan, Y., Alemdaroglu, U. (2017). Evidence of the relative age effect in youth soccer players from Turkey. Kinesiologia Slovenica, 23(2), 33-43.

Malina, R. (1994). Physical growth and biological maturation of young athletes. Exercise and Sport Sciences Reviews, 22, 389-434.

Malina, R.M., Eisenmann, J.C., Cumming, S.P. Riberio, B., \& Aroso, J. (2004). Maturity-associated variation in the growth and functional capacities of youth football (soccer) players 13-15 years. European Journal of Applied Physiology, 91, 555-562.

Mujika, I., Padilla, S., Angulo, P., Santisteban, J. (2007). Relative age effect in a professional football club setting. Journal of Sports Science and Medicine, 10(Suppl.), 62-65.

Mulazimoglu, O., Cihan, H., Erdogdu, M., Sirin, E.F. (2013). The relative age effect in professional and youth teams of some Turkish soccer clubs. Spormetre, 11(2), 105-11.

Musch, J. and Hay, R. (1999). The Relative Age Effect in Soccer: Cross- cultural evidence for a systematic distribution against children born late in the competition year. Sociology of Sport Journal, 16(1), 54-64.

Musch, J., \& Grondin, S. (2001). Unequal competition as an impediment to personal development: A review of the relative age effect in sport. Developmental Review, 21, 147 - 167.

Ostojic, SM, Castagna, C, Calleja-Gonzalez, J, Jukic, I, Idrizovic, K, \& Stojanovic, M. (1014). The biological age of 14-year-old boys and success in adult soccer: do early maturers predominate in the top-level game? Research in Sports Medicine, 22, 398-407.

Pena-Gonzalez, I., Fernandez-Fernandez, J., Moya-Ramon, M. \& Cervello, E. (2018) Relative age effect, biological maturation, and coaches' efficacy expectations in young male soccer players, Research Quarterly for Exercise and Sport, 89 (3), 373-379, DOI: 10.1080/02701367.2018.1486003.

Romann M, Fuchslocher J. (2011). Influence of the selection level, age and playing position on relative age effects in Swiss Women's soccer. Talent Development \& Excellence, 3(2), 239-247 
Sallaoui, R., Chamari, K., Chtara, M., Manai, Y., Ghrairi, M., Belhaouz, M., \& Baroon, A. (2014). The relative age effect in the 2013 FIFA U-17 Soccer World Cup competition. American Journal of Sports Science, 2(2), 35-40.

Sedano, S., Vaeyens, R., Redondo, J.C. (2015). The relative age effect in spanish female soccer players. Influence of the competitive level and a playing position. Journal of Human Kinetics, 46, 129-137. DOI: 10.1515/hukin-20150041.

Sherar, L.B., Baxter-Jones, A.D.G., Faulkner, R.A., Russell, K.W. (2007). Do physical maturity and birth date predict talent in male youth ice hockey players? Journal of Sports Sciences, 25, 879-886.

Verhulst, J. (1992). Seasonal birth distribution of West European soccer players: A possible explanation. Medical Hypotheses, 38, 346-348.

Yagüe, J.M., Rubia A., Sánchez-Molina, J., Maroto-Izquierdo, Molinero, O. (2018). The relative age effect in the 10 best leagues of male professional football of the Union of European Football Associations (UEFA). Journal of Sports Science and Medicine, 17, 409-416.

Ward, P., \& Williams, A. M. (2003). Perceptual and cognitive skill development in soccer: The multidimensional nature of expert performance. Journal of Sport and Exercise Psychology, 25, 93-111.

Wattie, N., Cobley, S., \& Baker, J. (2008). Towards a unified understanding of relative age effects. Journal of Sports Sciences, 26(13), 1403-1409. DOI: 10.1080/ 02640410802233034.

Weir, P.L, Smith, K.T, Peterson C, Horton S. (2010). Canadian women's ice hockey- evidence of a relative age effect. Talent Development \& Excellence, 2(2), 209-217.

Wiium, N., Liea, S.A., Ommundsenb, Y. \& Enksena, H.R. (2010). Does relative age effect exist among norwegian professional soccer players? International Journal of Applied Sports Sciences, 22(2), 66-76.

Williams, A.M. (2000). Perceptual skill in soccer: Implications for talent identification and development. Journal of Sports Sciences, 18, 737 - 740. 